\title{
CONFERÊNCIA DE HAUKE BRUNKHORST: APRESENTAÇÃO
}

\section{Sebastiáo Nascimento}

Hauke Brunkhorst é professor de sociologia e filosofia política e diretor do Departamento de Sociologia da Universidade de Flensburg. Sua área de trabalho atualmente se estende da constitucionalização no processo de integração europeia ao papel desempenhado pelas relações de solidariedade na sustentação das instituições democráticas e no reajuste das bases de integração em sociedades plurais, passando por uma aguda avaliação das implicações dos processos de secularização na transformação das estruturas sociais e políticas das sociedades pós-industriais.

Suas publicações de intervenção mais direta em debates em curso envolvem estudos sobre a renitência e a difusão da tortura, sobre esforços de superação da distância simbólica e institucional entre centro e periferia de sistemas políticos, sobre implicaçôes entre a integração europeia e a integração sul-americana, sobre a juridicização das relações internacionais e sobre a consolidação e as variaçôes do discurso de direitos humanos.
Ao longo de sua carreira, foi professor em Viena, Frankfurt, Berlim, Paris e, após ter recebido o Prêmio Theodor Heuss, por conta de seus esforços na internacionalização do panorama acadêmico alemão e por seu papel destacado na condução de pesquisas relacionadas com a tradição da teoria crítica e da teoria democrática, passou a ser também professor da New School for Social Research da Universidade de Nova York. De sua autoria, foi publicado recentemente o livro Solidarity (2005).

Sendo um dos intelectuais alemães mais prolíficos e reconhecidos na atualidade, sua presença no XXX Encontro Anual da Anpocs representou uma oportunidade singular para enriquecer o debate que se deu em grande número de grupos temáticos e mesas redondas, procurando avaliar os avanços recentes da pesquisa social realizada nas últimas décadas sobre temas relacionados com avanços e recuos nos processos de integração econômica e política nos continentes europeu e sul-americano, 
assim como avanços e recuos dos projetos de fortalecimento de instituiçôes democráticas, da mesma forma como a abordagem de tensões e conflitos relativos ao desenvolvimento econômico e à integração social e política de grupos minoritários.

Esta conferência sem dúvida ofereceu uma chance para que os pesquisadores e cientistas sociais brasileiros pudessem discutir abertamente tais desafios da investigação acadêmica com um representante destacado de uma corrente intelectual alemã que promove de maneira eficaz um diálogo transdisciplinar e transfronteiriço na busca de compreensão e avaliação mais aprofundadas e amplas de fenômenos e processos cujas causalidades e resultados já há muito se estendem para além de quaisquer limites nacionais e que convidam diferentes comunidades acadêmicas ao confronto de novas perspectivas, novas complexidades e novos parceiros para enfrentar os desafios contemporâneos no âmbito das ciências sociais. 